\title{
PENGARUH PENDIDIKAN PEMILIK, MASA MEMIMPIN, UMUR PERUSAHAAN, PELATIHAN AKUNTANSI, DAN EKSPEKTASI KINERJA TERHADAP PENGGUNAAN INFORMASI AKUNTANSI PADA UKM DI KABUPATEN MALANG
}

\author{
Febrinda Rizky Ramadhani*1, Puji Lestari'2, Saras Supeno ${ }^{3}$ \\ 1,2,3 Program Studi Akuntansi, Fakultas Ekonomi dan Bisnis, Universitas Jenderal Soedirman \\ Jl. HR Boenyamin No. 708 Purwokerto, Jawa Tengah, Indonesia \\ *Email Correspondence: ramadhanifebrinda@gmail.com
}

\begin{abstract}
This research aims to analyze and describe the factors that affect the use of accounting information in small and medium enterprises. Factors that used to affect the use of accounting information in this study are the owner educational background, lead time, bussiness age, accounting training, and performance expectancy. The population in this study was all of the potential SMEs in Kabupaten Malang. This research used proportionate stratified random sampling technique by determining sample to small group and medium group. Samples obtained in this research were 86 respondents. Data collection techniques with survey techniques with questionnaires distribution and data analysis techniques in this study using multiple regression analysis techniques with the help of SPSS software. The results of this research conclude that the application accounting information of SMEs is influenced by the owner educational background, the length of time owner managing, bussiness age, accounting training, and performance expectancy.
\end{abstract}

Keywords: owner educational background, lead time, bussiness age, accounting training, performance expectancy, the use of information accounting.

\begin{abstract}
Abstrak
Penelitian ini bertujuan untuk menganalisis dan menggambarkan faktor-faktor yang memengaruhi penggunaan informasi akuntansi pada Usaha Kecil dan Menengah. Faktor-faktor yang digunakan dalam penelitian ini adalah pendidikan pemilik, masa memimpin, umur perusahaan, pelatihan akuntansi, dan ekspektasi kinerja. Populasi dalam penelitian ini adalah seluruh UKM potensial di Kabupaten Malang. Penelitian ini menggunakan teknik proportionate stratified random sampling dengan membagi sampel menjadi 2 strata yaitu skala kecil dan skala menengah. Sampel yang diperoleh dalam penelitian ini sebanyak 86 responden. Teknik pengumpulan data dengan teknik survei dengan penyebaran kuesioner dan teknik analisis data dalam penelitian ini menggunakan teknik analisis regresi berganda dengan bantuan software SPSS. Hasil penelitian ini menyimpulkan bahwa penggunaan informasi akuntansi pada UKM dipengaruhi oleh pendidikan pemilik, masa memimpin, umur perusahaan, pelatihan akuntansi, dan ekspektasi kinerja.

Kata Kunci: pendidikan pemilik, masa memimpin, umur perusahaan, pelatihan akuntansi, ekspektasi kinerja, penggunaan informasi akuntansi
\end{abstract}

\section{PENDAHULUAN}

Perekonomian di Indonesia semakin berkembang dari tahun ke tahun. Hal ini salah satunya dipengaruhi oleh banyaknya perusahaan yang berkembang di Indonesia. Perusahan-perusahaan tersebut tersusun dari perusahaan besar, sedang, kecil, dan mikro. Salah satu sektor yang menjadi perhatian pemerintah adalah perusahaan sedang, kecil, dan mikro atau yang biasa disebut dengan UMKM. Sektor usaha kecil dan menengah atau UKM merupakan bentuk unit usaha yang dikelola oleh perorangan maupun kelompok dalam masyarakat. Peran UKM sangat penting bagi negara-negara berkembang seperti Indonesia dalam mengatasi berbagai permasalahan ekonomi maupun sosial, seperti mengurangi pengangguran, pemberantasan kemiskinan, dan pemerataan pendapatan. 
Penggerak perekonomian bangsa salah satunya adalah usaha kecil dan menengah (UKM). Astuti (2007) menyatakan, kekuatan ekonomi suatu negara memiliki korelasi positif dengan kontribusi usaha kecil dan menengah terhadap perekonomian suatu negara. Semakin besar kontribusi yang diberikan semakin kuat perekonomian negara tersebut.

Menurut Undang-Undang Nomor 20 Tahun 2008 tentang Usaha Mikro, Kecil, dan Menengah (UMKM), usaha kecil dan menengah adalah usaha ekonomi produktif yang berdiri sendiri, yang dilakukan oleh orang perorangan atau badan usaha yang bukan merupakan anak perusahaan atau bukan cabang perusahaan yang dimiliki, dikuasai, atau menjadi bagian baik langsung maupun tidak langsung dari usaha menengah atau usaha besar yang dengan jumlah kekayaan bersih atau hasil penjualan tahunan sebagaimana diatur dalam Undang-Undang ini.

Kendala yang dihadapi UKM di Indonesia secara umum mengalami keterbatasan modal kerja, kesulitan bahan baku, keterbatasan teknologi, sumber daya manusia dengan kualitas yang baik, informasi, dan pemasaran (Astuti, 2007). Lebih lanjut dijelaskan bahwa lemahnya usaha kecil di Indonesia bukan hanya disebabkan oleh kombinasi berbagai faktor tersebut, namun juga disebabkan oleh kurangnya dukungan dari pemerintah dan kurangnya kemauan pengusaha-pengusaha kecil dan menengah nasional untuk berorientasi global.

Pada dasarnya UKM memiliki peluang yang besar untuk mendapatkan kredit sebagai suntikan modal. Hingga saat ini banyak program pembiayaan bagi UKM yang baik dijalankan oleh pemerintah maupun oleh perbankan. Salah satu program pemerintah Indonesia terkait pembiayaan UKM adalah Kredit Usaha Rakyat (KUR) yang pada tahun 2015 menargetkan penyaluran KUR sebesar Rp 30 triliun. Alokasi anggaran program KUR bertujuan mendorong kontribusi sektor UKM terhadap penyerapan tenaga kerja, meningkatkan kontribusi dalam pembentukan Produk Domestik Bruto (PDB), pertumbuhan ekspor nonmigas, dan pertumbuhan investasi. (Kementrian Keuangan, 2015). Penyebab rendahnya penyaluran KUR tersebut disebabkan oleh sikap perbankan yang sangat selektif dalam menyalurkan KUR yang disalurkan tanpa menggunakan jaminan, untuk menghindari terjadinya kredit macet. Pemberian kredit atau pembiayaan oleh bank umum dalam rangka pengembangan UKM yang termuat dalam Peraturan Bank Indonesia Nomor 17/12/PBI/2015 pasal 5A menyatakan bahwa salah satu persyaratan penyaluran kredit kepada UKM dengan informasi akuntansi yang berupa laporan keuangan.

Pinasti (2007) juga menyatakan bahwa banyak UMKM yang belum menyelenggarakan pengelolaan keuangan dengan baik, apalagi menggunakan informasi akuntansi sesuai aturan dalam pengelolaan usahanya. Padahal dalam persaingan usaha yang semakin ketat, informasi akuntansi sangat diperlukan dalam rangka membantu memberikan berbagai informasi terkait dengan keuangan perusahaan, tetapi para pelaku usaha banyak yang tidak menyadari hal tersebut.

UKM di Kabupaten Malang mempunyai daya tarik tersendiri untuk diteliti karena mempunyai perkembangan yang cukup baik ditandai dengan terus meningkatnya jumlah UKM potensial di 
Pengaruh Pendidikan Pemilik, Masa..

Kabupaten Malang mencapai 630 unit. Hal itu bisa dicapai karena konsep dan kebijakan Kabupaten Malang dalam program optimalisasi pariwisata. Kabupaten Malang menjadikan Provinsi Bali sebagai panutan dalam hal penentuan konsep dan kebijakan tersebut. Menteri Koperasi dan Usaha Kecil Menengah (Menkop UKM) RI, Anak Agung Gede Ngurah Puspayoga menyatakan bahwa Bali bisa menjadi destinasi pariwisata kelas dunia sampai saat ini dikarenakan sektor UKM-nya juga terus dikuatkan dan pelakunya terus menerus ditingkatkan kesadarannya. Perdagangan di Pulau Dewata sangatlah tinggi dikarenakan pariwisatanya maju dan majunya pariwisata di Bali ditunjang penuh dengan adanya geliat produk dari UKM yang terus ditingkatkan produktivitasnya (Nana, 2017). Hal tersebut menjadi acuan peningkatan produktivitas UKM di Kabupaten Malang.

Bupati Kabupaten Malang, Rendra Kresna mengatakan bahwa usaha pemerintah untuk meningkatkan produktivitas UKM di Kabupaten Malang sedikit terhambat karena jumlah UKM yang menerapkan pencatatan akuntansi masih sedikit sehingga menyebabkan manajemen keuangan UKM menjadi lemah. Kondisi ini membuat usaha rentan mengalami kebangkrutan karena sesungguhnya pelaku UKM menjadi tolok ukur perekonomian daerah sekitar 80\% sampai 85\% (Martin, 2018). UKM di Kabupaten Malang khususnya pada usaha kecil dan menengah belum menyelenggarakan dan menggunakan informasi akuntansi secara maksimal dalam pengelolaan usahanya. Rendahnya penyelenggaraan dan penggunaan informasi akuntansi dalam pengelolaan UKM disebabkan oleh beberapa faktor antara lain persepsi terhadap urgensi keberadaan informasi akuntansi bagi UKM, pengetahuan akuntansi pemilik, staff, pertimbangan biaya-biaya manfaat dan ukuran bagi UKM (Astuti, 2007).

Penelitian yang dilakukan oleh Apriliawati (2011) menyatakan bahwa jenjang pendidikan sangat berpengaruh terhadap penggunaan informasi akuntansi. Semakin tinggi pendidikan pemilik/manajer akan menyebabkan peningkatan pengguaan informasi akuntansi pada perusahaan kecil dan menengah. Hasil penelitian tersebut tidak sama dengan penelitian yang dilakukan Astuti (2007) dan Kaukab, et al. (2014) menyatakan bahwa jenjang pendidikan yang dimiliki pemilik atau manajer tidak berpengaruh terhadap penggunaan informasi akuntansi. Informasi akuntansi tidak harus selalu dipengaruhi oleh jenjang pendidikan.

Chelsy \& Dina (2012) menemukan bahwa adanya pengaruh masa memimpin perusahaan yang signifikan terhadap penyiapan dan penggunaan informasi akuntansi pada perusahan kecil dan menengah di Kota Pekanbaru Hasil penelitian ini konsisten dengan hasil penelitian Handayani (2011). Pengalaman manajer dalam mengelola perusahaan akan terus bertambah seiring dengan masa jabatannya memimpin perusahaan. Semakin lama masa memimpin perusahaan seorang manajer, maka tingkat penyiapan dan penggunaan informasi akuntansi pun semakin tinggi. Hal ini disebabkan manajemen mempunyai keinginan untuk mengambil keputusan yang tepat dan cepat untuk pemecahan masalah yang dihadapinya. 
Apriliawati (2011) menemukan adanya pengaruh umur perusahaan terhadap penggunaan informasi akuntansi. Umur perusahaan adalah lamanya perusahaan beroperasi. Semakin lama usaha berdiri diharapkan usaha tersebut akan mengalami perkembangan. Perkembangan usaha yang signifikan akan diikuti dengan perkembangan informasi akuntansi yang semakin komplek. Sedangkan menurut penelitian Astuti (2007) tidak sependapat dengan hasil tersebut, bahwa umur tidak berpengaruh terhadap penggunaan informasi akuntansi. Hal ini dikarenakan aktivitas perusahaan yang tidak mengalami banyak perubahan dari tahun ke tahun, termasuk dalam hal keuangan. Sehingga tidak memberikan gambaran pengusaha (manajer) untuk meningkatkan pemanfaatan informasi akuntansi dalam perusahaannya.

Penelitian yang dilakukan Sitoresmi (2013) menyatakan bahwa pelatihan akuntansi berpengaruh terhadap penggunaan informasi akuntansi. Pelatihan seputar akuntansi sangat menentukan seberapa baik kemampuan seorang manajer akuntansi atau pemilik usaha terhadap penguasaan teknis akuntansi. Semakin sering seorang manajer akuntansi atau pemilik usaha mengikuti pelatihan akuntansi, maka semakin baik kemampuan manajer tersebut dalam menggunakan informasi akuntansi. Sedangkan menurut penelitian Siyami (2014) tidak sependapat dengan hasil tersebut bahwa pelatihan akuntansi tidak berpengaruh terhadap penggunaan informasi akuntansi. Hal ini disebabkan karena pengetahuan akuntansi tidak hanya didapatkan dari pelatihan akuntansi yang diikuti tetapi juga dari pendidikan yang ditempuh, pengalaman operasional perusahaan, maupun pengalaman pemilik atau manajer.

Ekspektasi kinerja dapat mempengaruhi penggunaan informasi akuntansi berdasarkan penelitian Whetyningtyas (2016) tentang determinan penggunaan informasi akuntansi pada usaha kecil menengah (UKM) menunjukkan bahwa ekspektasi knerja berpengaruh signifikan terhadap informasi akuntansi. Whetyningtyas (2016) berpendapat bahwa semakin tinggi ekspektasi kinerja seorang pemilik usaha kecil dan menengah maka akan meningkatkan penggunaan informasi akuntansi.

Berdasarkan latar belakang dan penelitian-penelitian sebelumnya yang telah diuraikan, maka peneliti tertarik melakukan penelitian kembali demi mengembangkan ilmu pengetahuan. Penelitian ini dilakukan pada UKM di Kabupaten Malang sehingga judul yang diambil adalah Pengaruh Pendidikan Manajer, Masa Memimpin, Umur Perusahaan, Pelatihan Akuntansi, dan Ekspektasi Kinerja terhadap Penggunaan Informasi Akuntansi pada UKM di Kabupaten Malang.

\section{TINJAUAN PUSTAKA}

\section{Pengaruh Pendidikan Pemilik terhadap Informasi Akuntansi}

Sitoresmi (2013) mengemukakan bahwa kemampuan dan keahlian pemilik usaha kecil dan menengah ini sangat ditentukan dari pendidikan formal yang pernah ditempuh. Pengetahuan pemilik dalam hal penyiapan dan penggunaan informasi akuntansi dapat dilihat dari jenjang pendidikan yang telah ditempuh. Apabila pemilik usaha hanya menempuh tingkat pendidikan yang rendah, maka pengetahuan 
Pengaruh Pendidikan Pemilik, Masa..

pemilik dalam hal penyiapan dan penggunaan informasi akuntansi masih rendah jika dibandingkan dengan pemilik yang menempuh tingkat pendidikan formal yang tinggi (perguruan tinggi). Hasil penelitian Apriliawati (2011) dan Siyami (2014) juga menyatakan bahwa terdapat pengaruh jenjang pendidikan terhadap penggunaan informasi akuntansi pada usaha kecil dan menengah.

Berdasarkan uraian di atas, hipotesis pertama yang diajukan adalah:

$\mathrm{H}_{1}$ : Pendidikan pemilik berpengaruh positif terhadap penggunaan informasi akuntansi.

\section{Pengaruh Masa Memimpin terhadap Informasi Akuntansi}

Manajemen mempunyai keinginan untuk mengambil keputusan secara tepat dan cepat untuk pemecahan masalah yang dihadapinya. Kebutuhan informasi akuntansi yang digunakan manajemen akan terasa apabila manajer membutuhkan informasi lebih banyak. Informasi yang diperoleh dari dalam maupun luar perusahaan dipengaruhi oleh masa memimpin perusahaan. Hasil penelitian Hariyadi (2013) dan Dewi (2016) menyatakan bahwa masa memimpin perusahaan berpengaruh terhadap penggunaan informasi akuntansi.

Berdasarkan uraian di atas, hipotesis kedua yang diajukan adalah:

$\mathrm{H}_{2}$ : Masa memimpin berpengaruh positif terhadap penggunaan informasi akuntansi.

\section{Pengaruh Umur Perusahaan terhadap Informasi Akuntansi}

Sitoresmi (2013) menyatakan bahwa umur perusahaan mengakibatkan perubahan pola pikir dan tingkat kemampuan pemilik perusahaan dalam pengambilan keputusan atas setiap tindakantindakannya. Pemilik perusahaan yang telah lama mengoperasikan usahanya telah banyak belajar dari pengalaman mereka daripada yang dilakukan oleh pemilik perusahaan yang baru mengoperasikan usahanya. Penelitian ini sependapat dengan Kristian (2010) dan Apriliawati (2011) menyatakan bahwa terdapat pengaruh umur usaha terhadap penggunaan informasi akuntansi pada usaha kecil dan menengah.

Berdasarkan uraian di atas, hipotesis ketiga yang diajukan adalah:

$\mathrm{H}_{3}$ : Umur perusahaan berpengaruh positif terhadap penggunaan informasi akuntansi.

\section{Pengaruh Pelatihan Akuntansi terhadap Informasi Akuntansi}

Solovida (2010) mengemukakan bahwa pemilik usaha yang sudah mendapatkan pelatihan akuntansi akan berusaha menggunakan informasi akuntansi dalam membuat keputusan bisnis sehingga dapat menjalankan usahanya dengan baik. Hasil penelitian Sitoresmi (2013) menemukan bahwa semakin sering pemilik atau manajer mengikuti pelatihan formal akuntansi maka akan menyebabkan peningkatan penggunaan informasi akuntansi pada KUB Sido Rukun Semarang. Kemampuan seorang pemilik terhadap penguasaan teknis akuntansi sangat ditentukan oleh pelatihan akuntansi yang pernah diikuti. Penelitian ini sependapat dengan Apriliawati (2011) dan Ikhwan (2016) menyatakan bahwa 
terdapat pengaruh pelatihan akuntansi terhadap penggunaan informasi akuntansi pada usaha kecil dan menengah.

Berdasarkan uraian di atas, hipotesis keempat yang diajukan adalah:

$\mathrm{H}_{4}$ : Pelatihan akuntansi berpengaruh positif terhadap penggunaan informasi akuntansi.

\section{Pengaruh Eksektasi Kinerja terhadap Informasi Akuntansi}

Ekspektasi kinerja (performance expectancy) sebagai tingkat dimana seorang individu akan merasa yakin bahwa kinerja usahanya dapat meningkat dan dapat terselesaikan dengan mudah apabila menggunakan suatu sistem. Hasil penelitian Whetyningtyas (2013) menyatakan bahwa harapan kinerja mempunyai pengaruh positif signifikan terhadap penggunaan informasi akuntansi pada UKM di Kabupaten Karanganyar.

Berdasarkan uraian di atas, hipotesis keempat yang diajukan adalah:

$\mathrm{H}_{5}$ : Ekspektasi kinerja berpengaruh positif terhadap penggunaan informasi akuntansi.

\section{METODE PENELITIAN}

\section{Populasi dan Teknik Pengambilan Sampel}

Jenis penelitian ini merupakan jenis penelitian kuantitatif. Populasi dalam penelitian ini adalah usaha kecil dan menengah (UKM) Kabupaten Malang yang terdaftar pada Dinas Koperasi dan UMKM Kabupaten Malang, dengan responden pemilik maupun manajer UKM. Sampel penelitian ini ditetapkan menggunakan teknik proportionate stratified random sampling. Data dikumpulkan dalam metode survei, yaitu menyebarkan daftar pertanyaan dalam kuesioner yang diisi atau dijawab oleh responden yaitu pemilik atau manajer UKM.

\section{Teknik Analisis Data}

Dalam penelitian ini, tahapan analisis data dimulai dengan uji validitas, uji reliabilitas, uji non response bias, uji asumsi klasik (uji normalitas, multikolinearitas, dan heteroskedastisitas), dan uji analisis regresi berganda dan pengujian hipotesis.

Pengujian hipotesis menggunakan uji t untuk mengetahui pengaruh secara parsial dengan tingkat kepercayaan yang digunakan adalah 95\%, nilai alpha $(\alpha)=0,05$. Persamaan regresi linier berganda dimaksud untuk menganalisis pengaruh dari variabel pendidikan pemilik (X1), masa memimpin(X2), umur perusahaan (X3), pelatihan akuntansi (X4), dan ekspektasi kinerja (X5) terhadap penggunaan informasi akuntansi (Y) dengan formula:

$Y=\alpha+b_{1} X_{1}+b_{2} X_{2}+b_{3} X_{3}+b_{4} X_{4}+b_{5} X_{5}+e$ 


\section{HASIL DAN PEMBAHASAN}

Hasil uji validitas instrumen penelitian, uji reliabilitas, dan uji non response bias terhadap butir pertanyaan dapat dikatakan valid dan reliabel. Dimana untuk uji validitas, semua item pertanyaan $r$ hitungnya lebih besar dari $r$ tabel $(0,235)$. Untuk uji reliabilitas, semua variabel cronbach alpha-nya lebih besar dari 0,6. Untuk uji non response bias, tingkat signifikansi dari semua variabel yaitu lebih besar dari 0,05 berdasarkan hasil Levene Test.

\section{Analisis Deskriptif Variabel Penelitian}

Analisis ini digunakan untuk mengetahui tanggapan umum dari responden terhadap variabel-variabel yang digunakan dalam penelitian ini. Variabel yang digunakan dalam penelitian ini adalah pendidikan pemilik, masa memimpin, umur perusahaan, pelatihan akuntansi, dan ekspektasi kinerja sebagai variabel independen dari penelitian ini. Variabel dependen dalam penelitian ini adalah penggunaan informasi akuntansi. Berdasarkan hasil penelitian, dapat disimpulkan bahwa responden memiliki persepsi yang tinggi terhadap semua variabel dilihat dari nilai rata-rata yang memiliki nilai lebih tinggi dari nilai titik tengahnya.

\section{Pengujian Asumsi Klasik}

Uji normalitas data menunjukkan data berdistribusi normal. Kemudian tidak terjadi multikolinearitas antar variabel bebas atau tidak terjadi korelasi antar variabel-variabel bebas dalam persamaan. Selanjutnya tidak terjadi heteroskedastisitas yang varian dari residual satu pengamatan ke pengamatan lain adalah tetap.

\section{Uji Analisis Regresi Berganda}

Dari hasil uji regresi linear berganda, didapatkan persamaan regresi yaitu:

$Y=-6,744+0,428 X_{1}+0,352 X_{2}+0,304 X_{3}+1,820 X_{4}+0,448 X_{5}+e$

Konstanta bernilai negatif yang berarti tingkat penggunaan informasi akuntansi akan bernilai -6,744 apabila variabel pendidikan pemilik $\left(\mathrm{X}_{1}\right)$, masa memimpin $\left(\mathrm{X}_{2}\right)$, umur perusahaan $\left(\mathrm{X}_{3}\right)$, pelatihan akuntansi $\left(\mathrm{X}_{4}\right)$, ekspektasi kinerja $\left(\mathrm{X}_{5}\right)$ bernilai nol dan tidak akan mengalami perubahan atau konstan. Koefisien variabel pendidikan pemilik $\left(\mathrm{X}_{1}\right)$ yaitu 0,428 artinya jika terjadi peningkatan pada variabel pendidikan pemilik sebesar satu satuan skor sedangkan variabel yang lain tetap atau konstan maka akan meningkatkan penggunaan informasi sebesar 0,428. Koefisien variabel masa memimpin $\left(\mathrm{X}_{2}\right)$ yaitu 0,352 artinya jika terjadi peningkatan pada variabel masa memimpin sebesar satu satuan skor sedangkan variabel yang lain tetap atau konstan maka akan meningkatkan penggunaan informasi sebesar 0,352. Koefisien variabel umur perusahaan $\left(\mathrm{X}_{3}\right)$ yaitu 0,304 artinya jika terjadi peningkatan pada variabel umur perusahaan sebesar satu satuan skor sedangkan variabel yang lain tetap atau konstan maka akan meningkatkan penggunaan informasi sebesar 0,304 . Koefisien variabel pelatihan 
akuntansi $\left(\mathrm{X}_{4}\right)$ yaitu 1,820 artinya jika terjadi peningkatan pada variabel pelatihan akuntansi sebesar satu satuan skor sedangkan variabel yang lain tetap atau konstan maka akan meningkatkan penggunaan informasi sebesar 1,820. Koefisien variabel ekspektasi kinerja $\left(\mathrm{X}_{5}\right)$ yaitu 0,448 artinya jika terjadi peningkatan pada variabel ekspektasi kinerja sebesar satu satuan skor sedangkan variabel yang lain tetap atau konstan maka akan meningkatkan penggunaan informasi sebesar 0,448.

\section{Pengujian Hipotesis}

\section{Pengaruh Pendidikan Pemilik terhadap Penggunaan Informasi Akuntansi}

Hasil pengujian hipotesis pertama menunjukan bahwa hubungan variabel pendidikan pemilik dengan penggunaan informasi akuntansi memiliki nilai signifikansi 0,005 dan nilai $\mathrm{t}_{\text {hitung }}$ sebesar 2,436. Nilai signifikansi $0,018 \leq \alpha 0,05$ dan nilai $t_{\text {hitung }}$ sebesar 2,436 $>$ nilai $t_{\text {tabel }}$ sebesar 1,66864. Kesimpulannya adalah signifikansi $\leq \alpha 0,05$ atau nilai $t_{\text {hitung }}>\mathrm{t}_{\text {tabel, }}$, maka hipotesis pertama didukung dalam penelitian ini. Sehingga dapat disimpulkan bahwa variabel pendidikan pemilik berpengaruh positif terhadap penggunaan informasi akuntansi sehingga hipotesis pertama diterima.

\section{Pengaruh Masa Memimpin terhadap Penggunaan Informasi Akuntansi}

Hasil pengujian hipotesis kedua menunjukan bahwa hubungan variabel masa memimpin dengan penggunaan informasi akuntansi memiliki nilai signifikansi 0,041 dan nilai $t_{\text {hitung }}$ sebesar 2,084. Nilai signifikansi $0,12 \leq \alpha 0,05$ dan nilai $t_{\text {hitung }}$ sebesar 2,084 $>$ nilai $t_{\text {tabel }}$ sebesar 1,66864. Kesimpulannya adalah signifikansi $\leq \alpha 0,05$ atau nilai $t_{\text {hitung }}>\mathrm{t}_{\text {tabel, }}$, maka hipotesis kedua didukung dalam penelitian ini. Sehingga dapat disimpulkan bahwa variabel masa memimpin berpengaruh positif terhadap penggunaan informasi akuntansi sehingga hipotesis kedua diterima.

\section{Pengaruh Umur Perusahaan terhadap Penggunaan Informasi Akuntansi}

Hasil pengujian hipotesis ketiga menunjukan bahwa hubungan variabel umur perusahaan dengan penggunaan informasi akuntansi memiliki nilai signifikansi 0,045 dan nilai $t_{\text {hitung }}$ sebesar 2,043. Nilai signifikansi $0,045 \leq \alpha 0,05$ dan nilai $t_{\text {hitung }}$ sebesar 2,043 $>$ nilai $t_{\text {tabel }}$ sebesar 1,66864. Kesimpulannya adalah signifikansi $\leq \alpha 0,05$ atau nilai $t_{\text {hitung }}>t_{\text {tabel }}$, maka hipotesis ketiga didukung dalam penelitian ini. Sehingga dapat disimpulkan bahwa variabel umur perusahaan berpengaruh positif terhadap penggunaan informasi akuntansi sehingga hipotesis ketiga diterima.

\section{Pengaruh Pelatihan Akuntansi terhadap Penggunaan Informasi Akuntansi}

Hasil pengujian hipotesis keempat menunjukan bahwa hubungan variabel pelatihan akuntansi dengan penggunaan informasi akuntansi memiliki nilai signifikansi 0,001 dan nilai $t_{\text {hitung }}$ sebesar 3,630. Nilai signifikansi $0,001 \leq \alpha 0,05$ dan nilai $t_{\text {hitung }}$ sebesar 3,630> nilai $t_{\text {tabel }}$ sebesar 1,66864. Kesimpulannya adalah signifikansi $\leq \alpha 0,05$ atau nilai $t_{\text {hitung }}>t_{\text {tabel }}$, maka hipotesis keempat didukung 
Pengaruh Pendidikan Pemilik, Masa...

dalam penelitian ini. Sehingga dapat disimpulkan bahwa variabel pelatihan akuntansi berpengaruh positif terhadap penggunaan informasi akuntansi sehingga hipotesis keempat diterima.

\section{Pengaruh Ekspektasi Kinerja terhadap Penggunaan Informasi Akuntansi}

Hasil pengujian hipotesis kelima menunjukan bahwa hubungan variabel ekspektasi kinerja dengan penggunaan informasi akuntansi memiliki nilai signifikansi 0,017 dan nilai $t_{\text {hitung }}$ sebesar 2,456 . Nilai signifikansi $0,017 \leq \alpha 0,05$ dan nilai $t_{\text {hitung }}$ sebesar $2,456>$ nilai $t_{\text {tabel }}$ sebesar 1,66864. Kesimpulannya adalah signifikansi $\leq \alpha 0,05$ atau nilai $t_{\text {hitung }}>\mathrm{t}_{\text {tabel }}$, maka hipotesis kelima didukung dalam penelitian ini. Sehingga dapat disimpulkan bahwa variabel ekspektasi kinerja berpengaruh positif terhadap penggunaan informasi akuntansi sehingga hipotesis kelima diterima.

Tabel 1. Hasil Uji

\begin{tabular}{ccc}
\hline Variabel & thitung $_{\text { }}$ & Sig. \\
\hline Pendidikan Pemilik $\left(X_{I}\right)$ & 2,436 & 0,018 \\
Masa Memimpin $\left(X_{2}\right)$ & 2,084 & 0,041 \\
Umur Perusahaan $\left(X_{3}\right)$ & 2,043 & 0,045 \\
Pelatihan Akuntansi $\left(X_{4}\right)$ & 3,630 & 0,001 \\
Ekspektasi Kinerja $\left(X_{5}\right)$ & 2,456 & 0,017 \\
\hline Sumber: Data primer diolah tahun 2018 &
\end{tabular}

\section{Pembahasan}

\section{Pengaruh Variabel Pendidikan Pemilik terhadap Penggunaan Informasi Akuntansi}

Hasil penelitian ini menunjukkan bukti bahwa kemampuan dan keahlian pemilik perusahaan sangat mempengaruhi penyiapan dan penggunaan informasi akuntansi. Tingkat pendidikan formal yang rendah menunjukkan rendahnya penyiapan dan penggunaan informasi akuntansi daripada pemilik perusahaan yang menempuh tingkat pendidikan lebih tinggi. Pendidikan yang ditempuh mendorong pemilik untuk memikirkan kelangsungan usahanya. Berlangsungnya usaha dengan jangka waktu yang lama salah satunya dipengaruhi oleh pengelolaan manajerial yang baik. Pengelolaan manajerial yang baik salah satunya dilakukan dengan pengelolaan keuangan yang baik. Apabila pengelolaan keuangan sudah dilakukan dengan baik, maka penerapan informasi akuntansi dapat dilakukan dengan mudah.

Hasil penelitian ini sesuai dengan penelitian yang dilakukan oleh Solovida (2010), Apriliawati (2011), dan Sitoresmi (2013). Penelitian tersebut menyatakan bahwa tingkat pendidikan formal pemilik UKM sangat memengaruhi penggunaan informasi akuntansi. Tingkatan pendidikan formal yang rendah membuat penggunaan informasi akuntansi pada UKM juga rendah dibandingkan dengan tingkatan formal yang tinggi. 


\section{Pengaruh Variabel Masa Memimpin terhadap Penggunaan Informasi Akuntansi}

Penelitian ini juga membuktikan bahwa pemilik perusahaan mengetahui informasi-informasi yang dibutuhkan oleh perusahaan seiring dengan pengalamannya memimpin perusahaan. Pemilik perusahaan pun semakin mudah dalam memahami dan menyusun informasi akuntansi dengan benar selama masa memimpin berjalan. Hal ini tentu berdampak terhadap perencanaan perusahaan yang semakin efektif. Perencanaan tersebut membuat aktivitas operasional perusahaan dapat dilakukan secara efektif sehingga dapat dengan mudah mencapai tujuan operasional perusahaan.

Hasil penelitian ini konsisten dengan hasil penelitian Handayani (2011). Seiring dengan masa jabatannya dalam memimpin perusahaan, pengalaman pemilik usaha akan semakin bertambah. Semakin lama masa memimpin perusahaan seorang pemilik, maka tingkat penyiapan dan penggunaan informasi akuntansi pun semakin tinggi. Hal ini disebabkan manajemen mempunyai keinginan untuk mengambil keputusan yang tepat dan cepat untuk pemecahan masalah yang dihadapinya. Kebutuhan informasi akuntansi yang digunakan untuk dasar pengambilan keputusan akan semakin dirasakan oleh para manajer agar alternatif pemilihan dapat diambil secermat mungkin.

\section{Pengaruh Variabel Umur Perusahaan terhadap Penggunaan Informasi Akuntansi}

Usaha yang sudah beroperasi dalam waktu yang lama akan mengetahui betapa pentingnya penggunaan informasi akuntansi dalam perusahaan. Informasi akuntansi tersebut berguna dalam implementasi strategi yang sudah ditetapkan dan proses pengendalian perusahaan. Posisi keuangan juga dapat diketahui dari penggunaan informasi akuntansi, sehingga dapat memudahkan perusahaan dalam pengambilan keputusan yang cepat dan tepat.

Penelitian ini sejalan dengan hasil penelitian yang dilakukan oleh Solovida (2010), Apriliawati (2011), dan Sitoresmi (2013) menyatakan bahwa umur usaha mempengaruhi penggunaan informasi akuntansi. Umur perusahaan yang semakin tua membuat penggunaan informasi akuntansi lebih intensif digunakan khususnya dalam hal pengambilan keputusan perusahaan.

\section{Pengaruh Variabel Pelatihan Akuntansi terhadap Penggunaan Informasi Akuntansi}

Selanjutnya, penelitian ini menunjukkan bahwa kemampuan seorang pemilik terhadap penguasaan teknis akuntansi ditentukan oleh seberapa banyak pelatihan akuntansi yang diikutinya. Pemilik usaha yang mengikuti pelatihan akuntansi cenderung lebih banyak menerapkan informasi akuntansi. Pelatihan akuntansi yang dimaksud adalah pelatihan akuntansi yang diikuti diluar lembaga luar pendidikan sekolah, diukur dari pelatihan, kursus serta seminar seputar keakuntansian yang pernah diikuti.

Penelitian ini sejalan dengan Solovida (2003), Apriliawati (2011), dan Sitoresmi (2013) yang menyatakan bahwa pelatihan seputar akuntansi sangat menentukan seberapa baik kemampuan seorang pemilik usaha terhadap penguasaan teknis akuntansi. Semakin sering seorang pemilik usaha 
Pengaruh Pendidikan Pemilik, Masa..

mengikuti pelatihan akuntansi, maka semakin baik kemampuan manajer tersebut dalam menggunakan informasi akuntansi.

\section{Pengaruh Variabel Eksektasi Kinerja terhadap Penggunaan Informasi Akuntansi}

Penelitian ini membuktikan bahwa ekspektasi kinerja dalam penelitian ini dapat meningkatkan keyakinan seorang pengusaha dalam menggunakan informasi akuntansi agar dapat meningkatkan kinerja usahanya. Penggunaan informasi akuntansi diharapkan dapat mempercepat pekerjaan dalam perusahaan. Selain itu, penggunaan informasi akuntansi dapat dijadikan pedoman dalam evaluasi kinerja usaha sehingga dapat dilakukan peningkatan kinerja. Penggunaan informasi akuntansi juga dapat meningkatkan produktivitas dan efektivitas usaha. Semua pekerjaan dapat dilakukan dengan mudah karena informasi akuntansi yang memiliki banyak manfaat dalam penggunaannya.

Hasil penelitian ini sejalan dengan hasil penelitian yang dilakukan oleh Whetyningtyas (2016) yang menyatakan bahwa ekspektasi kinerja berpengaruh positif terhadap sikap individu untuk menggunakan informasi akuntansi pada UKM.

\section{KESIMPULAN}

\section{Kesimpulan}

Kesimpulan yang diperoleh dari hasil penelitian ini antara lain (1) pendidikan pemilik berpengaruh positif terhadap penggunaan informasi akuntansi, (2) masa memimpin berpengaruh positif terhadap penggunaan informasi akuntansi, (3) umur perusahaan berpengaruh positif terhadap penggunaan informasi akuntansi, (4) pelatihan akuntansi berpengaruh positif terhadap penggunaan informasi akuntansi, (5) ekspektasi kinerja berpengaruh positif terhadap penggunaan informasi akuntansi.

\section{Keterbatasan}

Keterbatasan penelitian ini adalah para pemilik usaha kecil dan menengah di Kabupaten Malang pada awalnya banyak yang enggan mengisi kuisioner karena memiliki persepsi yang berbeda tentang penelitian ini. Mereka mempersepsikan bahwa penelitian ini berkaitan dengan perpajakan dari pemerintah sehingga mereka khawatir pajak usahanya akan dinaikkan seiring dengan dilakukannya penelitian. Hal ini akan mengakibatkan jawaban responden menjadi kurang objektif. Selain itu, para pemilik usaha kecil dan menengah di Kabupaten Malang merasa bahwa bahasa yang digunakan pada kuesioner terlalu akademis yang sulit untuk dipahami dan dimengerti oleh kalangan UKM, sehingga menimbulkan jawaban yang bias.

\section{Saran}

Berdasarkan hasil penelitian dan pembahasan dalam penelitian ini, penulis menyarankan hal-hal sebagai berikut: (1) Peneliti selanjutnya diharapkan dapat meyakinkan para pemilik usaha kecil dan menengah bahwa penelitian ini merupakan penelitian yang independen, tidak berkaitan dengan perpajakan 
maupun pemerintahan. (2) Peneliti selanjutnya diharapkan dapat menjelaskan kepada para pemilik usaha kecil dan menengah tentang isi kuesioner dengan bahasa yang mudah dipahami dan dimengerti oleh mereka, serta menambahkan beberapa pertanyaan terbuka pada kuesioner agar mereka dapat berpendapat sesuai dengan pemahaman mereka tentang informasi akuntansi. (3) Peneliti selanjutnya diharapkan untuk menambah sampel penelitian sehingga dapat memperluas cakupan penelitian. (4) Para pemilik usaha kecil dan menengah diharapkan terus meningkatkan proses belajar dengan selalu mengikuti pelatihan yang dapat meningkatkan kemampuannya dalam penggunaan informasi akuntansi sehingga keberhasilan usaha dapat tercapai. (5) Para pemilik usaha kecil menengah diharapkan dapat lebih meningkatkan penerapan informasi akuntansi pada perusahaannya setelah mendapatkan ilmu pengetahuan mengenai manfaat penggunaan informasi akuntansi.

\section{DAFTAR PUSTAKA}

Anugrah, Yusrani. 2015. Analisis Faktor - Faktor Yang Mempengaruhi Pemahaman Usaha Mikro Kecil Dan Menengah (UMKM) Dalam Penggunaan Informasi Akuntansi. Skripsi. UMJ. Jember

Apriliawati, Y dan Hastuti. 2011. Identifikasi Faktor Penggunaan Informasi Akuntansi pada Perusahaan Kecil di Kota Bandung. Jurnal Ekonomi, Keuangan, Perbankan dan Akuntansi. Vol 3, No, 2, Hal $350-370$.

Astuti, Era. 2007. Pengaruh Karakteristik Internal Perusahaan Terhadap Penyiapan dan Penggunaan Informasi Akuntansi Perusahaan Kecil dan Menengah di Kabupaten Kudus. Tesis. Program Magister Akuntansi UNDIP.

Chelsy, Dina Hidayat. 2012. Analisis Faktor-Faktor yang Mempengaruhi Penyiapan dan Penggunaan Informasi Akuntansi pada Perusahaan Kecil dan Menengah di Kota Pekanbaru. Jurnal Ekonomi, Manajemen dan Akuntansi Universitas Islam Riau. 19, (2), 11-28.

Daryoto, Dwi. 2009. Laporan Keuangan UMKM Butuh Ditingkatkan. http://nasional.kompas.com/read/2009/08/27/18561480/laporan.keuangan.umkm.butu h.ditingkatkan. Diakses pada tanggal 22 Januari 2018.

Davis, F.D. 1989. Perceived Usefulness, Perceived Ease of Use, and Acceptance of Information System Technology. MIS Quarterly 13 (3): 319-339.

Dinas Koperasi dan UMKM Pemerintah Kabupaten Malang. 2017. Data UKM di Kabupaten Malang Tahun 2017. Malang.

Ghozali, Imam. 2011. "Aplikasi Analisis Multivariate Dengan Program SPSS". Semarang: Badan Penerbit Universitas Diponegoro.

Ghozali, Imam. 2013. Aplikasi Analisis Multivariate Dengan Program SPSS. Edisi ketujuh, Semarang : Badan Penerbit Universitas Diponegoro.

Handayani, Bestari Dwi. 2011. Faktor yang Mempengaruhi Penggunaan Informasi Akuntansi Usaha Kecil dan Menengah. Akuntabilitas. Sept 2011, Vol.11, No.1, ISSN 1412 - 0240. 
Pengaruh Pendidikan Pemilik, Masa...

Hariyadi. 2013. Faktor-Faktor yang Mempengaruhi Penggunaan Informasi Akuntansi Pada Usaha Mikro, Kecil dan Menengah (UMKM) Yang Bergerak Di Bidang Jenis Usaha Makanan Di Kota Tanjungpinang.

Haswel, S., and Homes, S., 1989, "Estimating the Small Business Failure Rate: A Reappraisal", Journal of Small Business Management.

Holmes, S., and Nicholls, D. 1988. An Analysis of The Use of Accounting Information by Australian Small Busines. Journal of Small Business Management, 26 (20).57-68.

Jogiyanto, 2010. Analisis dan Desain Sistem Informasi, Edisi IV, Andi Offset, Yogyakarta

Kaukab et al. 2014. Pengaruh Skala Usaha, Sektor Industri, Lama Usaha, Pendidikan Manajer/Pemilik, Pelatihan Akuntansi dan Masa Memimpin Perusahaan Terhadap Penggunaan Informasi Akuntansi. Fakultas Ekonomi UNSIQ. Wonosobo.

Kementerian Koperasi dan UMKM. 2008. UU No 20 Tahun 2008 Tentang UMKM.

Kementerian Koperasi dan UMKM. 2016. Perkembangan data usaha mikro, kecil dan menengah (UMKM). www.depkop.go.id. Diunduh tanggal 20 Januari 2018.

Marshall B. Romney dan Paul John Steinbart. 2006. Sistem Informasi Akuntansi. Salemba Empat. Jakarta.

Martin. 2018. Pertumbuhan Ekonomi Kabupaten Malang Berasal Dari UKM. http://www.mitratoday.com/pertumbuhan-ekonomi-kabupaten-malang-berasal-dariukm/. Diakses pada tanggal 22 Januari 2018.

Nana. 2017. Pesan Menteri Koperasi UKM untuk Kabupaten Malang: Kalau Ingin Maju Pariwisatanya, Kuat UKM. http://www.malangtimes.com/baca/22910/20171130/193805/pesan-menterikoperasi-ukm-untuk-kabupaten-malang--kalau-ingin-maju-pariwisatanya-kuatkan-umkmL. Diakses pada tanggal 22 Januari 2018.

Pinasti, Margani. 2007. Pengaruh Penyelenggaraan dan Penggunaan Informasi Akuntansi terhadap Persepsi Pengusaha Kecil Atas Informasi Akuntansi. Jurnal Riset Akuntansi Indonesia Vol.10/No.3/2007. Fakultas Ekonomi Universitas Hasanuddin. Makassar.

Sitoresmi, LD. 2013. Faktor-Faktor Yang Mempengaruhi Penggunaan Informasi Akuntansi Pada UKM KUB Sido Rukun Semarang. Diponegoro Journal of Accounting. Vol.2, No.3, Hal.1-13. ISSN 2337-3806.

Siyami, Nur. 2014. Analisis Penggunaan Sistem Informasi Akuntansi pada Usaha Kecil dan Menengah di Purworejo. Seminar Nasioanal dan The $3^{\text {rd }}$ Call for Syriah Paper. ISSN 2480-0784. UMS.

Solovida, G. T. 2010. "Faktor - Faktor yang Mempengaruhi Penyiapan dan Penggunaan Informasi Akuntansi pada Perusahaan Kecil dan Menengah di Jawa Tengah", Jurnal Prestasi, Vol. 6 No. 1 - Juni 2010.

Sugiyono. 2012. Metode Penelitian Pendidikan. Bandung: Alfabeta.

Sugiyono. 2014. Metode Penelitian Pendidikan Pendekatan Kuantitatif, Kualitatif Dan R\&D. Bandung: Alfabeta.

Suliyanto. 2005. Metode Riset Bisnis. Yogyakarta: CV. Andi Offset.

Suliyanto. 2011. Ekonometrika Terapan: Teori dan Aplikasi dengan SPSS. Yogyakarta: ANDI. 
Whetyningtyas, Aprilia. 2016. Determinasi penggunaan informasi akuntansi pada usaha kecil dan menengah. Media Ekonomi Dan Manajemen. Vol. 31 No. 2 Juli 2016.

Yayuk, Widiyanti. 2013. Analisis Faktor-Faktor Yang Mempengaruhi Persepsi Penguaha Kecil Dan Menengah Atas Penggunaan Informasi Akuntansi Keuangan (Studi Pengusaha Kecil Dan Menengah Di Sentra Kerajinan Tas Kain Kabupaten Kendal). Fakultas Ekonomi Universitas Negeri Semarang. 